\title{
Summertime tropospheric-ozone variability over the Mediterranean basin observed with IASI
}

\author{
C. Doche ${ }^{1, *}$, G. Dufour ${ }^{1}$, G. Foret ${ }^{1}$, M. Eremenko ${ }^{1}$, J. Cuesta ${ }^{1}$, M. Beekmann ${ }^{1}$, and P. Kalabokas ${ }^{2,3}$ \\ ${ }^{1}$ Laboratoire Inter-universitaire des Systèmes Atmosphériques (LISA), Universités Paris-Est Créteil et Paris Diderot, \\ CNRS, Créteil, France \\ ${ }^{2}$ Academy of Athens, Research Center for Atmospheric Physics and Climatology, Athens, Greece \\ ${ }^{3}$ European Commission, JRC, Institute for Environment and Sustainability, Air and Climate Unit, Ispra, Italy \\ *now at: Météo France, Direction Inter-Régionale Sud-Ouest, Division Etudes et Climatologie, Mérignac, France
}

Correspondence to: C. Doche (clement.doche@meteo.fr)

Received: 28 February 2014 - Published in Atmos. Chem. Phys. Discuss.: 21 May 2014

Revised: 4 September 2014 - Accepted: 6 September 2014 - Published: 9 October 2014

\begin{abstract}
The Mediterranean basin is one of the most sensitive regions in the world regarding climate change and air quality. This is partly due to the singular dynamical situation of the Mediterranean basin that leads to tropospheric-ozone concentrations that are among the highest over the Northern Hemisphere. Six years of summertime tropospheric ozone observed by the Infrared Atmospheric Sounding Interferometer (IASI) instrument from 2007 to 2012 have been analysed to document the variability of ozone over this region. The satellite observations have been examined together with meteorological analyses (from ECMWF) to understand the processes driving this variability. Our work confirmed the presence of a steep west-east ozone gradient in the lower troposphere with the highest concentrations observed over the eastern part of the Mediterranean basin. This gradient is mainly explained by diabatic convection over the Persian Gulf during the Indian monsoon season, which induces an important subsidence of ozone-rich air masses from the upper to the lower troposphere over the central and the eastern Mediterranean basin. IASI observations of ozone concentrations at a $3 \mathrm{~km}$ height show a clear summertime maximum in July that is well correlated to the maximum of downward transport of ozone-rich air masses from the upper troposphere. Even if this feature is robust over the six analysed years, we have also investigated monthly ozone anomalies - one positive (June 2008) and one negative (June and July 2009) - using daily IASI observations. We show that the relative position and the strength of the meteorological systems (Azores anticyclone and Middle Eastern depression) present
\end{abstract}

over the Mediterranean are key factors in explaining both the variability and the anomalies of ozone in the lower troposphere in this region.

\section{Context and problems}

Lower-tropospheric ozone $\left(\mathrm{O}_{3}\right)$ is a pollutant harmful to both human health and vegetation (Levy et al., 2001; Fuhrer, 2009). In the upper troposphere, ozone acts as a powerful greenhouse gas (IPCC, 2007). The presence of ozone throughout the troposphere depends on the meteorological conditions driving vertical and horizontal transport and on photochemical ozone production from its precursors (mainly nitrogen oxides $\mathrm{NO}_{\mathrm{x}}$ and volatile organic compounds VOCs; Delmas et al., 2005; Camredon and Aumont, 2007; Jacob, 2000). Understanding the ozone variability and documenting it well are crucial with respect to both climate change and air quality (Volz-Thomas et al., 2003). The Mediterranean basin is sensitive to both climate change and atmospheric pollution, mainly during summer. Indeed, climate change experts expect an intensification of the summertime dryness (IPCC, 2007) which is already typical for this region. The combination of the specific meteorological conditions prevailing during summer and the regional air pollution emissions produce an enhancement of lower-tropospheric-ozone concentrations over this area (Nolle et al., 2001; Lelieveld et al., 2002; Kalabokas and Repapis, 2004; Velchev et al., 2011). These summertime meteorological conditions are characterized by 
two high-pressure ridges - one over central Europe and one over the western Mediterranean basin - and a deep trough extending from the Persian Gulf to the eastern Mediterranean basin (Fig. 1a). The central Europe ridge results from an extension of the Azores anticyclone, while the western ridge results from an extension of the North African anticyclone. These systems lead to low winds, persistent clearsky conditions and high solar irradiation over the Mediterranean (Prezerakos, 1984; Tyrlis and Lelieveld, 2013; Anagnostopoulou et al., 2014). The eastern trough is associated with the strong convection linked to the summertime Indian monsoon (Fig. 1b; for further information see also Alpert et al., 2005). Indeed, the ascending motion induced by the Indian monsoon produces a cellular circulation, which leads to strong descending winds just over the central and eastern Mediterranean. This corresponds to one of the strongest occurrences of subsidence over the entire Northern Hemisphere (about $0.15 \mathrm{~Pa} \mathrm{~s}^{-1}$ in the south of Greece, see Fig. $1 \mathrm{~b}$ and also Ziv et al., 2004). In addition, a lower-tropospheric northsouth circulation, referred to as Etesian winds, occurs over the central Mediterranean basin between these two meteorological systems (east of Greece; Ziv et al., 2004). These meteorological conditions favour (1) the horizontal transport of polluted air masses, with potentially high ozone concentrations, from eastern continental Europe to the Mediterranean Sea (Kalabokas et al., 2008; Richards et al., 2013) and (2) the vertical downward transport of ozone-enriched air masses from the upper troposphere and the lower stratosphere. Moreover, the persistence of anticyclonic conditions, associated with high solar irradiation and low winds, can induce photochemical ozone production within the plumes of the densely urbanized areas located along the Mediterranean coast, although the regional background ozone levels are generally more important (Kalabokas and Repapis, 2004).

Over the eastern Mediterranean basin, the presence of an ozone pool in the middle troposphere has been noticed by several observational and modelling studies (e.g. Marenco et al., 1998; Stohl et al., 2001; Jonson et al., 2001; Li et al., 2001; Roelofs et al., 2003; Liu et al., 2009; Zanis et al., 2014). Most of these studies suggest that this ozone pool is likely produced by downward transport from the upper troposphere and lower stratosphere. In addition, the impact of European emissions on ozone concentrations over the eastern basin within the boundary layer has been estimated by Richards et al. (2013), and this contribution remains limited. Kalabokas et al. (2013) show that high ozone concentrations in the lower troposphere are related to anticyclonic events, which reinforce subsidence and the Etesian advection of potentially ozone-enriched air masses coming from Europe. Following these authors, low ozone concentrations in the lower troposphere are related to cyclonic conditions, characterized by advection of oceanic ozone-poor air masses from the Atlantic to the Mediterranean. These studies are mainly based on accurate in situ observations from ozone sondes or MOZAIC/IAGOS (Measurement of OZone and
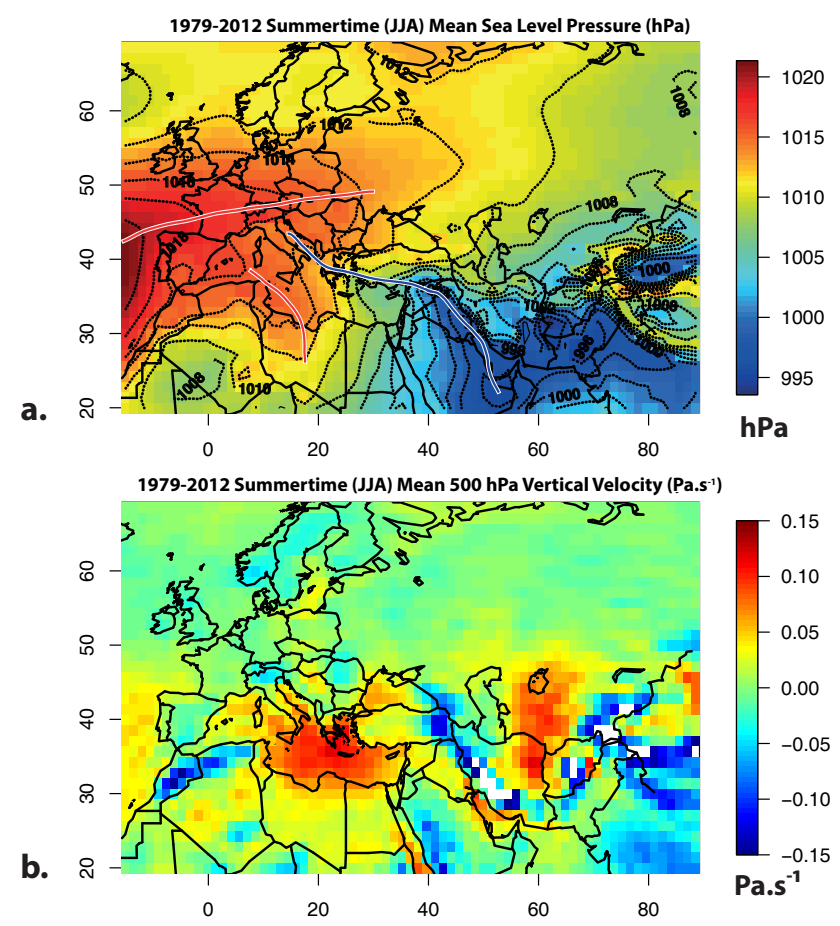

Figure 1. 1979-2012 summertime (June, July and August) averages of meteorological variables taken from $12 \mathrm{~h}$ ERA-Interim reanalysis: (a) sea level pressure (hPa) (colour shading and black contour lines) - the red lines represent the high-pressure ridges and the blue line the deep trough; (b) $500 \mathrm{hPa}$ vertical velocity $\left(\mathrm{Pa} \mathrm{s}^{-1}\right.$ ) (white colour corresponds to out-of-range values).

water vapor by Airbus in-service airCraft/In-service Aircraft for a Global Observing System) vertical profiles and surface stations (Kalabokas et al., 2013; Zbinden et al., 2013), but their specific geographic and temporal sampling only provides an incomplete vertical description of the troposphere over the entire basin. Model simulations have been used by Richards et al. (2013) and Zanis et al. (2014) to describe the tropospheric-ozone distribution, although their coarse resolution may induce large uncertainties.

Satellite observations provide interesting opportunities to complement these model and in situ measurement approaches. Indeed, in the last decade, satellite observations of tropospheric ozone have been developed and have become more and more precise (e.g. Fishman et al., 2003; Liu et al., 2005; Coheur et al., 2005; Worden et al., 2007; Eremenko et al., 2008). These observations are now able to complement in situ observations, offering wide spatial coverage and good horizontal resolution. Thermal infrared nadir sounders like the Tropospheric Emission Spectrometer (TES) instrument (Beer et al., 2001) aboard EOS-AURA (Earth Observing System - Aura) and the Infrared Atmospheric Sounding Interferometer (IASI) instrument aboard MetOp (Clerbaux et al., 2009) provide a maximum of sensitivity in the mid-troposphere with an effective vertical resolution of about 
6-7 km and have been used to study atmospheric composition and transport, climate and air quality (e.g. Worden et al., 2008; Jones et al., 2008; Eremenko et al., 2008; Boynard et al., 2009; Dufour et al., 2010; Safieddine et al., 2013). Richards et al. (2013) and Zanis et al. (2014) have used ozone observations derived from TES and/or GOME-2 (Global Ozone Monitoring Experiment - 2) to confirm the presence of the ozone pool over the eastern Mediterranean basin. In the present study, ozone observations derived from IASI measurements using the approach developed by Eremenko et al. (2008) are used to document the spatiotemporal variability of lower- and upper-tropospheric ozone over the Mediterranean basin during summertime. One advantage of IASI with respect to TES is that IASI's scanning capacity offers a quasi-global coverage twice a day with dense horizontal sampling (pixels spaced by $25 \mathrm{~km}$ at nadir). Moreover, compared to UV sounders, IASI measurements exhibit much better sensitivity to lower-tropospheric-ozone concentrations (Cuesta et al., 2013; Foret et al., 2014). In the present study, 6 years of IASI observations are analysed and compared to meteorological reanalyses from the ECMWF ERA-Interim model in order to evaluate the role of the atmospheric dynamical processes in tropospheric-ozone distribution and its variability over the Mediterranean basin. This study complements previous studies, adding a new independent set of observations with relatively fine horizontal resolution and good sensitivity to lower-tropospheric ozone. The very large number of individual IASI measurements allows us to conduct month-to-month analyses (for summer periods) over the Mediterranean in the lower free troposphere (at around a $3 \mathrm{~km}$ altitude) and to focus on ozone anomalies analyses with respect to the climatological mean on a daily scale.

The IASI ozone observations used for the present study are described in Sect. 2, as are the meteorological data and the analysis method. In Sect. 3, summertime spatiotemporal variability of ozone over the Mediterranean basin is analysed in parallel with meteorological conditions for the 2007-2012 period. From this analysis, two tropospheric-ozone anomalies with respect to the climatological evolution are identified in June 2008 and June/July 2009. They are discussed in Sect. 4. Conclusions are given in Sect. 5.

\section{Ozone observations and methodology}

\subsection{IASI measurements of tropospheric ozone}

\subsubsection{The IASI instrument}

The IASI instrument (Clerbaux et al., 2009), on board the MetOp-A platform since 19 October 2006, is a nadir-viewing Fourier transform spectrometer operating in the thermal infrared between 645 and $2760 \mathrm{~cm}^{-1}$ with an apodized spectral resolution of $0.5 \mathrm{~cm}^{-1}$. The IASI field of view is composed of a $2 \times 2$ matrix of pixels with a diameter at nadir of
$12 \mathrm{~km}$ each. IASI scans the atmosphere with a swath width of $2200 \mathrm{~km}$, allowing the monitoring of atmospheric composition twice a day at any (cloud-free) location. The spectral coverage and the radiometric and spectral performances of IASI allow this instrument to measure the global distribution of several important atmospheric trace gases (e.g. Boynard et al., 2009; George et al., 2009; Clarisse et al., 2011). Concerning ozone, three to four pieces of information are available for the overall retrieved profile, depending on the thermal conditions. In the troposphere, up to $1.5^{\circ}$ of freedom are observed under favourable thermal conditions. In particular, Dufour et al. (2010) have shown the ability of IASI to capture separately the ozone variability in the lower and upper troposphere under summer conditions, thus enabling the use of this variability in air quality studies of polluted regions.

\subsubsection{Ozone retrieval}

The ozone profiles considered in the present study are retrieved using the method described in Eremenko et al. (2008). These IASI ozone observations are well validated and characterized (Keim et al., 2009; Dufour et al., 2012). Briefly, the retrievals are based on the radiative transfer model KOPRA (Karlsruhe Optimized and Precise Radiative transfer Algorithm; Stiller et al., 2000) and its inversion module KOPRAFIT (Karlsruher optimierte und genaue Strahlungstransport-Algorithmus) (Hopfner et al., 2001). A constrained least-squares-fit method using an analytical altitude-dependent regularization is used (Kulawik et al., 2006). The applied regularization method is detailed in Eremenko et al. (2008). Compared to previous studies using this algorithm (Eremenko et al., 2008; Dufour et al., 2010, 2012), a selection of one of two a priori ozone profiles has been added, which is based on the detection of the tropopause height. Tropopause height is calculated from the temperature profile retrieved from IASI using the definition based on the lapse rate criterion (WMO, 1957). A threshold (14 km) has also been selected for choosing the a priori and the regularization matrix. If the tropopause height is lower (higher) than $14 \mathrm{~km}$, a constraint and a priori typical for midlatitudes (tropics) are used. The regularization matrices are those already used in Eremenko et al. (2008) for the midlatitudes and in Dufour et al. $(2010,2012)$ for the tropics. The a priori profiles used during the retrieval are compiled from the climatology of McPeters et al. (2007). The midlatitude a priori profile is set to the climatological profile of the $30-60^{\circ} \mathrm{N}$ latitude band for summer and the tropical a priori profile is set to the climatological profile of the $10-30^{\circ} \mathrm{N}$ latitude band for 1 year. It has been checked that the use of two different a priori and constraints does not induce discontinuities in the retrieved ozone fields. This reduces possible oscillations in the ozone profile induced by compensation effects during the retrieval procedure, especially in the tropics. 


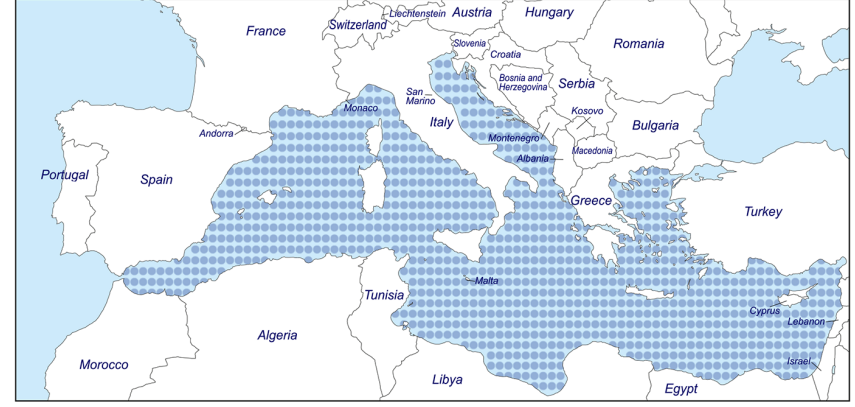

Figure 2. Sea mask used to calculated ozone averages over the Mediterranean (blue dots). The dots represent the grid cells considered in the averages.

Table 1. Mean relative bias and root mean square of errors (RMSE) of IASI ozone observations at 3 and $10 \mathrm{~km}$. They are derived from the comparison of IASI observations and ozone-sonde measurements at Madrid and Ankara over the summertime periods between 2007 and 2012 (see text for more details). Bias and RMSE are given in percent and in ppbv (in parenthesis).

\begin{tabular}{lrr}
\hline & Bias & RMSE \\
\hline $3 \mathrm{~km}$ & $-3.2(2)$ & $16(10)$ \\
$10 \mathrm{~km}$ & $15.8(16)$ & $21(21)$ \\
\hline
\end{tabular}

\subsubsection{Validation}

The IASI ozone product used in this study has been extensively characterized and validated using ozone sondes (Keim et al., 2009; Dufour et al., 2012). Dufour et al. (2012) showed that the mean bias in the lower troposphere from the surface to $6 \mathrm{~km}$ is $-2 \%$ ( $-0.38 \mathrm{DU})$ for typical midlatitude measurements. In the midlatitudes, the main difference between IASI and the ozone sondes arises in the UTLS (upper troposphere and lower stratosphere) column (between 8 and $16 \mathrm{~km}$ ) with a bias of $13.2 \%$ (6.3 DU) on average. In the tropics, the biases are larger: $-6.2 \%(-1.5 \mathrm{DU})$ in the lower troposphere (between surface and $8 \mathrm{~km})$ and $23.6 \%(6.1 \mathrm{DU})$ in the UTLS (between 11 and $20 \mathrm{~km}$ ). As the present study is focused on the Mediterranean basin during summer and some modifications in the retrieval algorithm have been made, we performed a specific validation restricted to the summer period for the two WOUDC (World Ozone and Ultraviolet Radiation Data Centre) ozone-sonde stations located closest to the Mediterranean (Madrid and Ankara). The number of available ozone-sonde profiles is 72 over the validation period (summers between 2007 and 2012). The same coincidence criteria $\left( \pm 1^{\circ}\right.$ in longitude and latitude and $\left.7 \mathrm{~h}\right)$ as in Dufour et al. (2012) have been used. The mean bias for the lowertropospheric column is $-1.9 \%(-0.4 \mathrm{DU})$, similar to the one from Dufour et al. (2012). The mean bias for the UTLS column $(16.5 \%, 5.0 \mathrm{DU})$ is slightly larger than the bias reported by Dufour et al. (2012) for an entire year for all the mid-

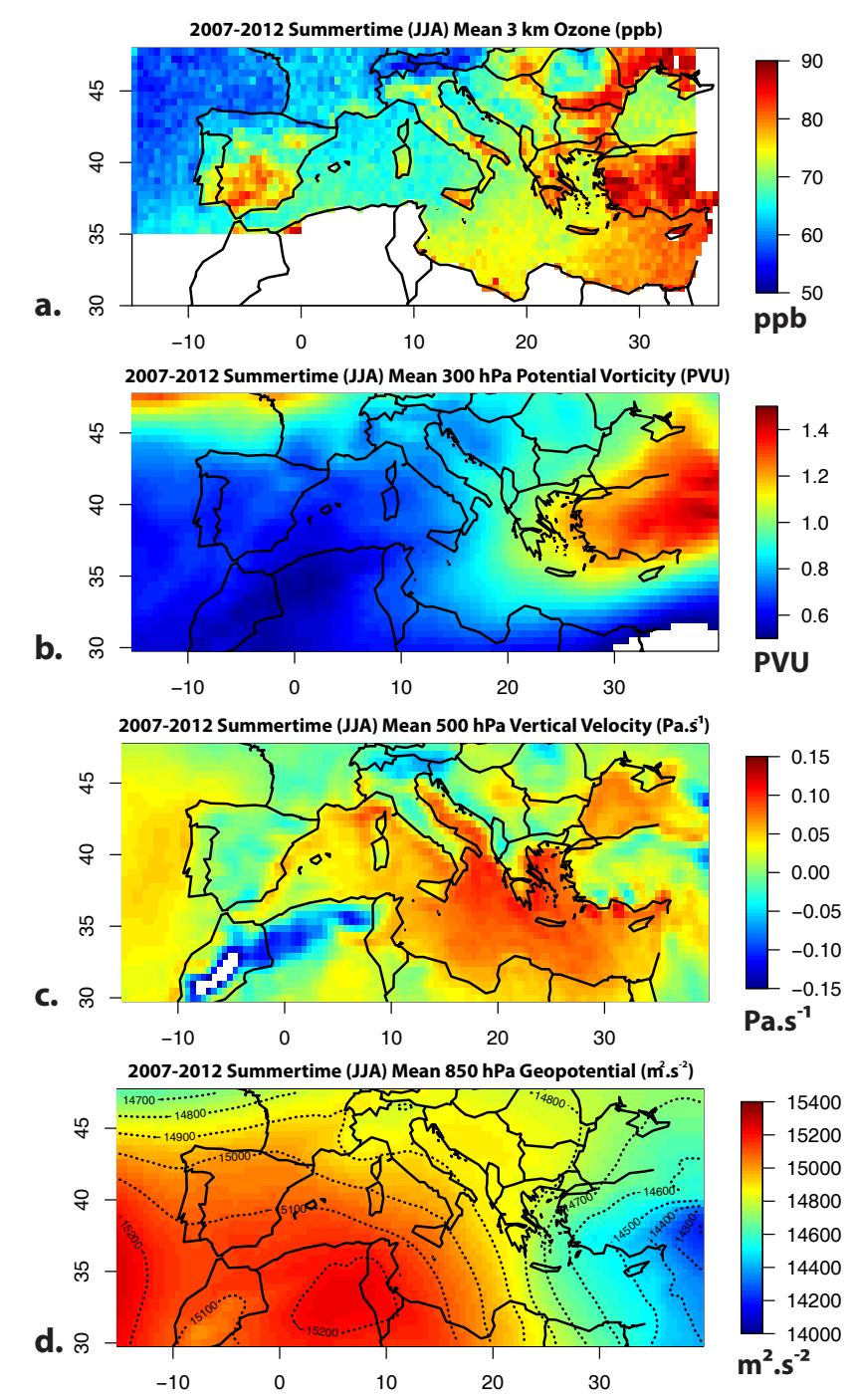

Figure 3. 2007-2012 summertime (June, July and August) average of ozone measured by IASI (morning overpasses) and meteorological variables taken from $12 \mathrm{~h}$ ERA-Interim reanalysis: (a) $3 \mathrm{~km}$ ozone concentration (ppb); (b) $300 \mathrm{hPa}$ potential vorticity (PVU); (c) $500 \mathrm{hPa}$ vertical velocity $\left(\mathrm{Pa} \mathrm{s}^{-1}\right)$; (d) $850 \mathrm{hPa}$ geopotential $\left(\mathrm{m}^{2} \mathrm{~s}^{-2}\right)$.

latitude ozone-sonde stations. Indeed, a larger bias for the summer season for this part of the atmosphere has already been noticed (see Fig. 12 in Dufour et al., 2012). Several hypotheses (coarse vertical resolution, spectroscopic and radiative transfer uncertainties) have been discussed by Dufour et al. (2012) to explain this bias. We refer the reader to this paper for more details. In the present study, we make the choice to present ozone concentrations rather than columns. We consider ozone concentrations at $3 \mathrm{~km}$ (a.s.l.) and $10 \mathrm{~km}$ (a.s.l.). Table 1 gives the mean bias and error estimates (given by the root mean square of the difference between IASI and the ozone sondes) at these two levels. Results are consistent with those derived for the lower-tropospheric and UTLS 


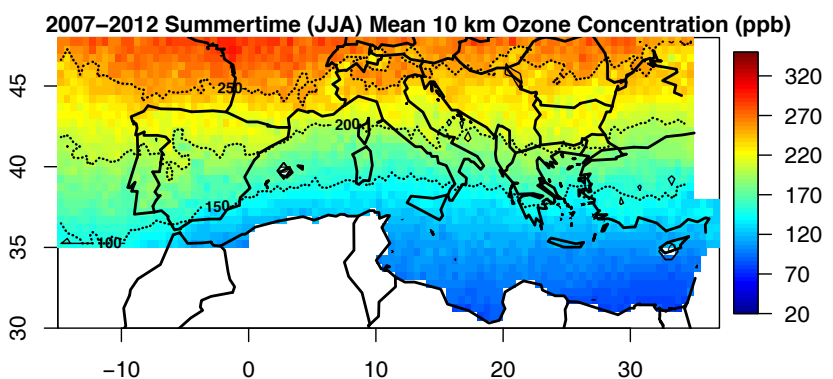

Figure 4. 2007-2012 summertime (June, July and August) average of $10 \mathrm{~km}$ ozone (ppb) measured by IASI (morning overpasses).

columns as well as with the validation exercise reported in Dufour et al. (2012). It is worth noting that some caution has to be exercized when interpreting the ozone distributions derived from IASI observations. Due to the reduced vertical sensitivity and resolution of IASI, ozone concentrations retrieved at $3 \mathrm{~km}$ describe the ozone variability from roughly 2 to $8 \mathrm{~km}$ (lower/mid-troposphere), and ozone concentrations retrieved at $10 \mathrm{~km}$ describe the ozone variability from 5 to $14 \mathrm{~km}$ (upper troposphere/lower stratosphere) (Dufour et al., 2010). Moreover, the height of maximum sensitivity for one level (i.e. the atmospheric layer up to which the measurement is the most representative) can vary significantly from one pixel to another. This may happen mainly in the vicinity of the coasts, where the thermal contrast, driving the sensitivity of the observations, can vary dramatically from a land to a sea pixel, leading to some discontinuity in the retrieved ozone fields as the atmospheric layers sounded may be different. One example of this arises in Fig. 3a in the Black Sea area.

\subsection{Methodology to analyse tropospheric ozone over the Mediterranean}

Our analyses are based on the morning overpasses of IASI, in which the thermal conditions are more favourable for retrieving relevant information in the lower troposphere. The monthly and daily variations of ozone at a 3 and $10 \mathrm{~km}$ altitude during the summertime period are used. Monthly averages over the considered IASI observation period (20072012) are used as a reference to analyse the ozone variability and anomalies. In the following, averages over the 6-year period are referred to as a climatology for convenience even if 6 years is too short a period to clearly address a climatological mean. A land/sea mask has been applied to calculate only the averages over the Mediterranean Sea (Fig. 2). The role of the atmospheric dynamical processes for the tropospheric-ozone distribution and its variability over the Mediterranean basin is then assessed by comparing ozone observations to meteorological reanalyses. The meteorological data used in this study are taken from the ECMWF ERA-Interim Analysis atmospheric model. It is characterized by a $12 \mathrm{~h} 4-\mathrm{D}-$ Var data as-

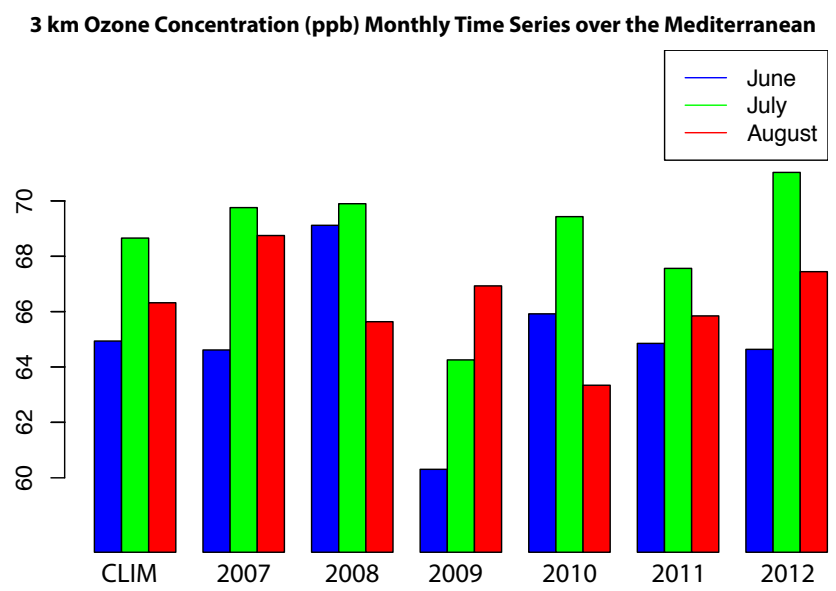

Figure 5. Monthly means of $3 \mathrm{~km}$ ozone concentrations (ppb) measured by IASI during the summertime period between 2007 and 2012 over the Mediterranean (IASI morning overpasses). Only the observations over the sea are considered in the averages. The monthly means referred to as "CLIM" represent the averages over the entire period (2007-2012).

similation system, a $0.75^{\circ} \times 0.75^{\circ}$ horizontal resolution and 91 vertical layers (Dee et al., 2011). The meteorological parameters are taken at 12:00 UTC for this study. The $850 \mathrm{hPa}$ geopotential is used as a proxy for describing the lowertropospheric horizontal transport. It allows the characterization of the meteorological systems, their relative positions and strength as well as the induced flux direction. The 200 and $300 \mathrm{hPa}$ potential vorticity (PV) fields are used as tracers of the (partial) stratospheric character of air masses and of vertical exchange processes. Indeed, stratospheric ozonerich air masses are characterized by large potential vorticity corresponding to enhanced vertical stability (Holton, 1992). This induces a positive vertical gradient of PV as well as of ozone in the UTLS. A positive temporal correlation between ozone and PV can thus be interpreted as a dynamic control (control by transport processes) of ozone concentrations, both due to the alternative presence of air masses with varying tropopause height and stratospheric character and due to subsidence of air from the UTLS region down to the middle troposphere (e.g. Beekmann et al., 1994). In this study, the ozone concentrations observed by IASI at the $10 \mathrm{~km}$ level can be compared to the $200 \mathrm{hPa}$ potential vorticity to infer the dynamic control of the ozone concentration variability. The PV at $300 \mathrm{hPa}$ turned out to best describe vertical transport from the lower stratosphere down to the mid-troposphere, especially when important subsidence is present. Note that potential vorticity at lower altitudes is less reliable for such an analysis due to the nonconservative character of PV in the troposphere induced by diabatic processes (Holton, 1992). These contributions of ozone in the mid-troposphere are analysed using IASI retrievals at $3 \mathrm{~km}$. 
$300 \mathrm{hPa}$ Potential Vorticity (PVU) Monthly Time Series over the Mediterranean

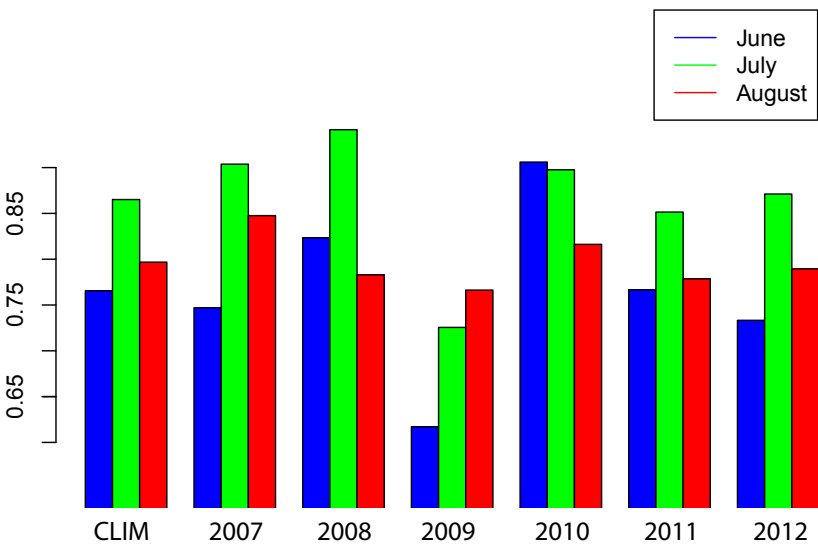

Figure 6. Same as Fig. 5 for $300 \mathrm{hPa}$ potential vorticity (PVU) taken from $12 \mathrm{~h}$ ERA-Interim reanalysis.

\section{Summertime ozone spatiotemporal variability during the 2007-2012 period}

In this section, we analyse the variability of ozone over the Mediterranean basin at the lower $(3 \mathrm{~km})$ and the upper $(10 \mathrm{~km})$ troposphere using 6 years of IASI observations. A month-to-month analysis and daily ozone anomaly analyses with respect to the climatological evolution are conducted. Results are discussed with respect to the associated meteorological conditions. Figure 3a shows the mean ozone concentrations retrieved with IASI at $3 \mathrm{~km}$ over the Mediterranean basin for the six summers (June, July and August) between 2007 and 2012. Higher ozone values are located in the eastern part of the Mediterranean basin. The $3 \mathrm{~km}$ ozone concentrations inferred from IASI range between 70 and $80 \mathrm{ppbv}$ in this region, in agreement with in situ measurements made during summertime periods (e.g. Kalabokas et al., 2013). At this altitude over the basin, a steep horizontal west-east ozone gradient is observed, with greater concentrations east of $15^{\circ}$ (by about $20 \mathrm{ppb}$ ) than west of this. The highest ozone values are observed over Turkey, where the $300 \mathrm{hPa}$ potential vorticity is also the largest (Fig. 3b). The large PV values indicate an activation of the vertical exchanges due to the presence of the trough in this region. The large vertical downward velocities at $500 \mathrm{hPa}$ east of $15^{\circ} \mathrm{E}$ (Fig. 3c) suggest that the downward vertical transport of ozone-enriched air masses from the upper troposphere to the lower troposphere can explain the enhancement of ozone over the eastern Mediterranean basin in the lower troposphere. It should be noted that the downward vertical transport actually takes place at the western flank of the high PV streamer (Fig. 3b) as theoretically expected from a dynamical point of view (Hoskins, 1985). Apart from the important role of subsidence, the high probability of tropopause folds over the area should also be considered. This phenomenon advects stratospheric air into the upper and middle troposphere. Tyrlis et al. (2014) indi-

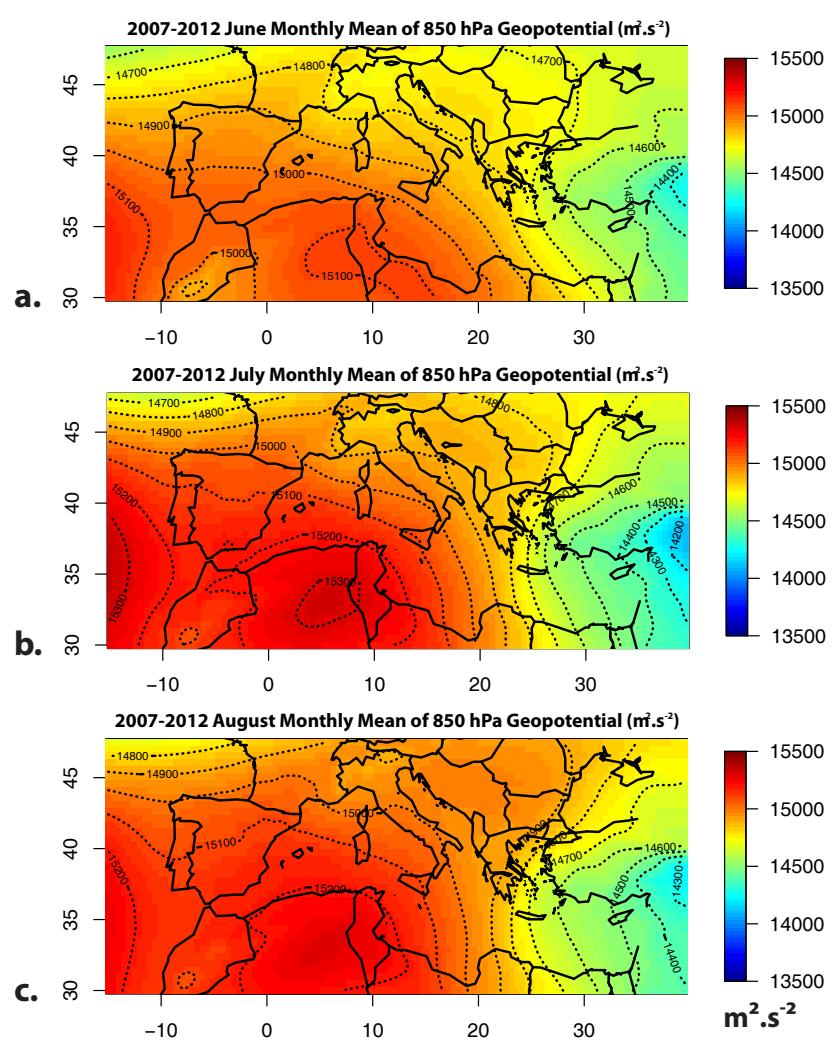

Figure 7. 2007-2012 monthly mean of $850 \mathrm{hPa}$ geopotential $\left(\mathrm{m}^{2} \mathrm{~s}^{-2}\right)$ taken from $12 \mathrm{~h}$ ERA-Interim reanalysis (colour shading and black contour lines) for (a) June, (b) July and (c) August.

cate a global "hot spot" of summertime tropopause fold activity over a sector between the eastern Mediterranean and Afghanistan, in the vicinity of the subtropical jet. According to a study by Sprenger et al. (2007), a maximum in stratosphere-to-troposphere transport (STT) is identified at the western flank of the stratospheric PV streamers, which implies a collocation with the area of the strongest subsidence. The observed ozone gradient over the Mediterranean is then mainly associated with the pronounced subsidence over the central and eastern Mediterranean basin, arising from the diabatic convection over the Persian Gulf during the Indian monsoon. These results are in agreement with previous studies based on in situ measurements (Kalabokas et al., 2013) and model analyses (Zanis et al., 2014). In addition, it is worth noting that the western part of the basin is located downwind of the Atlantic Ocean and influenced by advection of more pristine air masses (Fig. 3d). For the western basin, ozone enhancements occur over shorter time periods and are usually local events. They can be explained by local dynamics such as sea breeze that can transport polluted air masses over the sea (Velchev et al., 2011; Millan et al., 2000). The low sensitivity of IASI near the surface, where these local processes arise, makes their observation difficult. Note that the west-east gradient of ozone can be potentially 


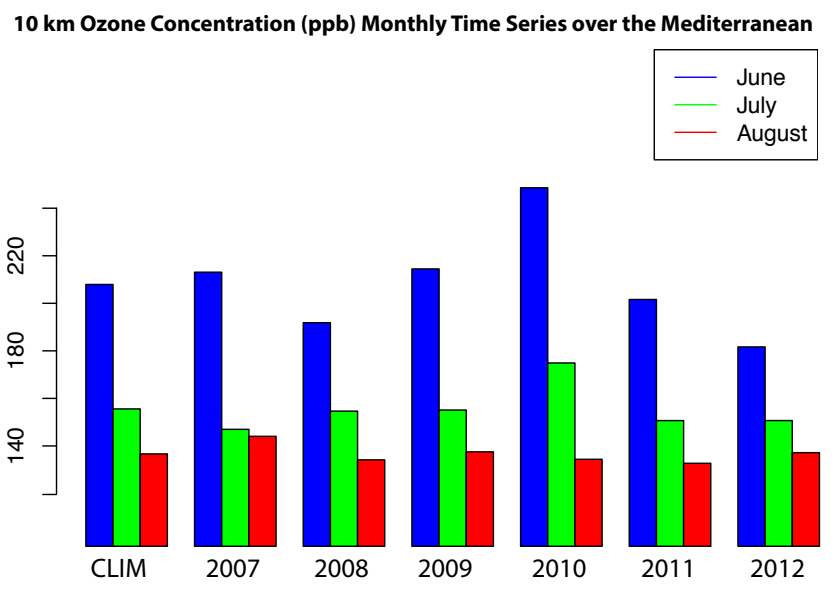

Figure 8. Same as Fig. 5 for $10 \mathrm{~km}$ ozone concentrations measured by IASI.

reinforced by the Etesian winds in the lower troposphere, which transport air masses from European continental areas. For comparison, we also analyse the ozone distribution observed by IASI in the upper troposphere $(10 \mathrm{~km})$ during summer (Fig. 4). This comparison shows that the ozone concentrations retrieved from IASI at $3 \mathrm{~km}$ (Fig. 3a) and at $10 \mathrm{~km}$ (Fig. 4) are clearly uncorrelated and that IASI observations provide reliable information on the ozone spatial variability in the lower and the upper troposphere. As expected, a north-south horizontal gradient is observed in the upper troposphere (Fig. 4).

The large number of IASI observations available provides the opportunity to investigate the temporal variability of ozone over the Mediterranean basin on an interannual scale and on a monthly basis. The monthly variability of ozone on the scale of the basin has been investigated very little, and satellite observations have not, to our knowledge, been exploited for this purpose. The temporal variability of lower-tropospheric ozone is driven by both the vertical and horizontal dynamics of the troposphere. Indeed, our analysis suggests that vertical exchanges between the higher and the lower troposphere lead to a maximum of the monthly mean $3 \mathrm{~km}$ ozone concentration in July (Fig. 5). This lowertropospheric maximum is correlated to a $300 \mathrm{hPa}$ potential vorticity maximum, occurring also in July (Fig. 6). The Pearson correlation coefficient between ozone concentrations at $3 \mathrm{~km}$ (Fig. 5) and potential vorticity at $300 \mathrm{hPa}$ (Fig. 6), calculated over the 3 summer months of the 6 considered years, is 0.99 . The correlation is calculated from 18 data points $(6$ years $\times 3$ months). The ozone maximum corresponds also to an $850 \mathrm{hPa}$ geopotential maximum in July. Indeed, the North African anticyclone is stronger in July with values higher than $15300 \mathrm{~m}^{2} \mathrm{~s}^{-2}$ (Fig. 7b) compared to June (maximum values of $15100 \mathrm{~m}^{2} \mathrm{~s}^{-2}$, Fig. 7a) and August (maximum values of $15200 \mathrm{~m}^{2} \mathrm{~s}^{-2}$, Fig. 7c). In addition, the depression over the eastern basin is deeper in July $\left(14200 \mathrm{~m}^{2} \mathrm{~s}^{-2}\right.$,

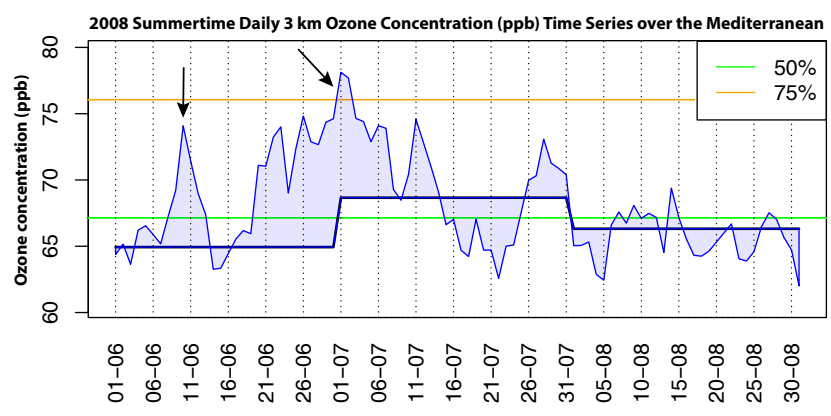

Figure 9. 2008 summertime day-to-day mean $3 \mathrm{~km}$ ozone concentrations(ppb) time series measured by IASI (thin blue curve) over the Mediterranean (IASI morning overpasses). Only the observations over the sea are considered in the averages. 2007-2012 $3 \mathrm{~km}$ ozone concentration monthly means are plotted as the thick dark blue curve. Horizontal coloured lines represent the 2007-2012 summertime (JJA) $3 \mathrm{~km}$ ozone quantiles for the data set of individual profiles.

Fig. 7a) than in June $\left(14400 \mathrm{~m}^{2} \mathrm{~s}^{-2}\right.$, Fig. 7a) and in August $\left(14300 \mathrm{~m}^{2} \mathrm{~s}^{-2}\right.$, Fig. 7c). This also indicates that the northsouth horizontal advection flux located between these two systems is more pronounced during July, potentially leading to an additional enhancement of ozone concentrations due to the transport of ozone-enriched air masses from Europe. Tyrlis and Lelieveld (2013) have shown that the strength of Etesian winds and of the subsidence over the Mediterranean basin are at a maximum in July and that these maxima were temporally very well correlated with the monsoon convection over northern India. As a consequence, the variability of ozone concentrations at a $3 \mathrm{~km}$ height over the Mediterranean basin is characterized by a maximum in July. This feature seems fairly stable over different years (Fig. 5); nevertheless, a few anomalies with respect to the average behaviour are also present. Especially during the summer of 2009, the monthly mean ozone concentration at a $3 \mathrm{~km}$ height increases between June and August, with particularly low values for June and July (about $60 \mathrm{ppbv}$ for June 2009 as compared to about 65 ppbv for the 2007-2012 June monthly ozone mean at $3 \mathrm{~km}$ ). The summer of 2008 also shows an anomaly compared to the climatology, with a large ozone concentration at $3 \mathrm{~km}$ in June (about $69 \mathrm{ppbv}$ compared to about $65 \mathrm{ppbv}$ for the 2007-2012 June monthly mean of $3 \mathrm{~km}$ ozone concentration). A detailed analysis provides a better understanding of how the dynamics control the ozone concentrations over the Mediterranean basin. A day-to-day analysis of these anomalies is presented in the next section.

By comparison, we also present the interannual variations of summer monthly average concentrations at a $10 \mathrm{~km}$ height, which is different compared to that at $3 \mathrm{~km}$ (Fig. 8). The monthly mean ozone in the upper troposphere decreases from June to August with a marked maximum in June (Fig. 8). This ozone decrease is related to the well-known annual cycle of ozone that presents a midlatitude spring 


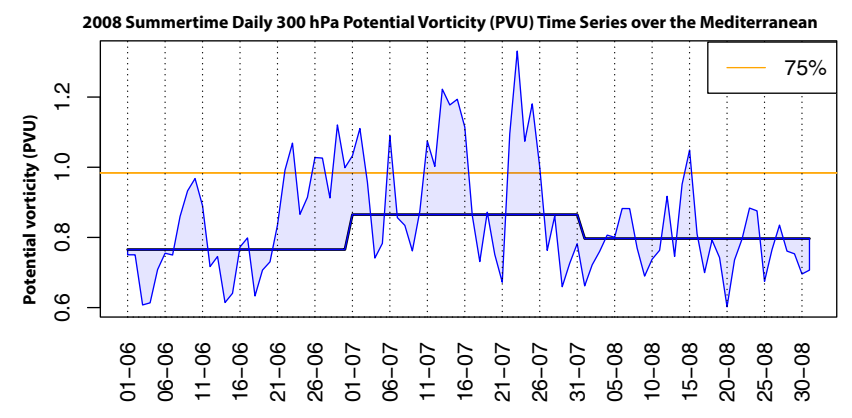

Figure 10. Same as Fig. 9 for the 2008 summertime daily mean of $300 \mathrm{hPa}$ potential vorticity (PVU) time series over the Mediterranean (12 h ERA-Interim reanalysis).

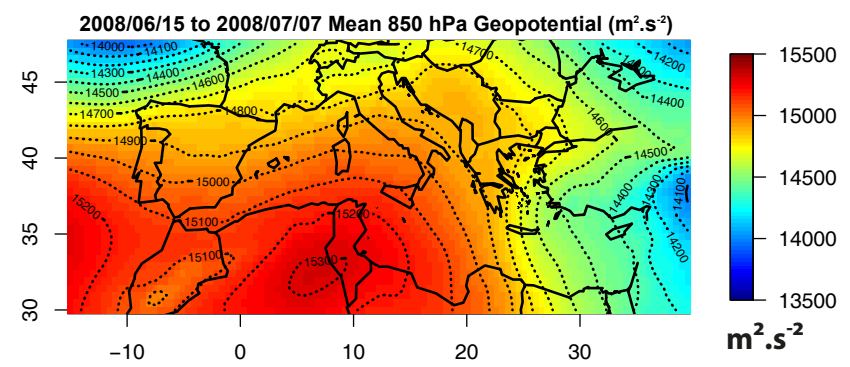

Figure 11. Mean $850 \mathrm{hPa}$ geopotential $\left(\mathrm{m}^{2} \mathrm{~s}^{-2}\right)$ for the 15 June 2008-7 July 2008 period. The data are taken from $12 \mathrm{~h}$ ERA-Interim reanalysis.

maximum at these altitudes. The interannual variability of upper-tropospheric ozone is weak, especially in July and August, and the June-August concentration decreases persist over the 6 years.

\section{Anomaly analysis: June 2008 and June/July 2009}

In the $3 \mathrm{~km}$ ozone monthly variations presented in Fig. 5, two years (2008 and 2009) present anomalies compared to the climatological average between 2007 and 2012. During the summer of 2008, June ozone concentrations at $3 \mathrm{~km}$ are significantly larger than for the other years, whereas during the summer of 2009, ozone concentrations increase progressively from June to August with unusually low ozone values in June and July. In this section, we present an analysis of the meteorological situation for the two specific years that explains the anomalies.

\subsection{The case of June 2008}

In order to explain the June 2008 positive ozone anomaly, we investigate the link between the synoptic meteorological conditions and the ozone daily variations for this month. Figure 9 shows that two high-ozone events are observed by IASI at a $3 \mathrm{~km}$ altitude: one around 10 June 2008 and another one between 20 June 2008 and 4 July 2008 (Fig. 9).
The ozone concentrations averaged over the Mediterranean Sea during these periods are about $72.5 \mathrm{ppbv}$, much more than the median value $(64 \mathrm{ppbv})$ calculated over the 6-year period. For 2 days (1-2 July 2008), the ozone values even exceed the $75 \%$ quartile (76 ppbv) calculated over all the ozone profiles measured over the basin. Studying the eastern and the western basin separately shows that the eastern basin is the most affected. Ozone concentrations exceed $80 \mathrm{ppb}$ during these periods and even exceed the $93 \%$ quartile for some days, whereas the ozone concentrations remain lower than $70 \mathrm{ppb}$ on average over the western basin (not shown). These two events are well correlated to the $300 \mathrm{hPa}$ potential vorticity, which also presents two maxima for the same periods with values of about $1 \mathrm{PVU}$ over the Mediterranean basin (Fig. 10). The Pearson correlation coefficient between the $300 \mathrm{hPa}$ potential vorticity and the $3 \mathrm{~km}$ ozone concentration time series is 0.87 for the month of June 2008. This again suggests that the large ozone amount observed in this case is related to the vertical exchanges with the upper troposphere. This is confirmed by the analysis of the daily Indian Monsoon Index (IMI, http://apdrc.soest.hawaii.edu/projects/ monsoon/seasonal-monidx.html), which indicates positiveanomaly events in the diabatic convective activity over the Indian Ocean during the month of June 2008. In addition, the $3 \mathrm{~km}$ ozone concentration time series is also correlated with the $850 \mathrm{hPa}$ geopotential time series, both time series being averaged over the entire basin. The Pearson correlation coefficient is about 0.85 . Figure 11 shows the mean $850 \mathrm{hPa}$ geopotential for the period between 15 June 2008 and 7 July 2008. The Azores anticyclone was stronger during this period compared to the mean situation between 2007 and 2012 (Fig. 7a). It was also located at higher latitudes. The ridge over the western Mediterranean basin is then strengthened as is the horizontal Etesian flux over the lower troposphere of the central and eastern Mediterranean basin. In addition, the low-pressure system located in the eastern part of the basin is also deeper during this period compared to the mean over the 6-year period, suggesting an intensification of the vertical subsidence of ozone-rich air masses. This is also confirmed by larger vertical descending winds at $500 \mathrm{hPa}$ for June 2008 compared to the climatological mean (relative difference of $14.3 \%)$.

\subsection{The case of June and July 2009}

As in the previous case, we analysed the meteorological conditions and the daily ozone variations for June and July 2009 (Fig. 12). A low-ozone episode is observed by IASI between 9 and 25 June 2009 and in the first half of July 2009, with $3 \mathrm{~km}$ ozone values below the median and even below the first quartile between 11 and 21 June 2009 (Fig. 12). The daily $300 \mathrm{hPa}$ potential vorticity over the Mediterranean presents moderate values (0.6 PVU) and indicates low vertical exchange activity (Fig. 13). The potential vorticity at $300 \mathrm{hPa}$ is not correlated with the $3 \mathrm{~km}$ ozone time series for June 


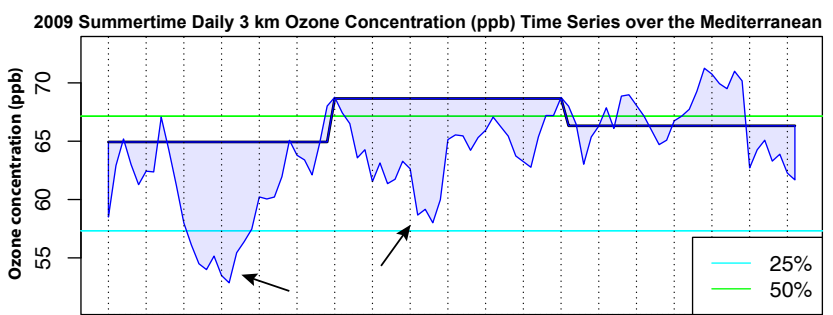

\& \& \& \& \&

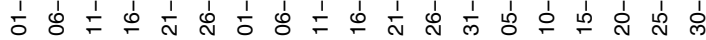

Figure 12. Same as Fig. 9 for the summer of 2009.

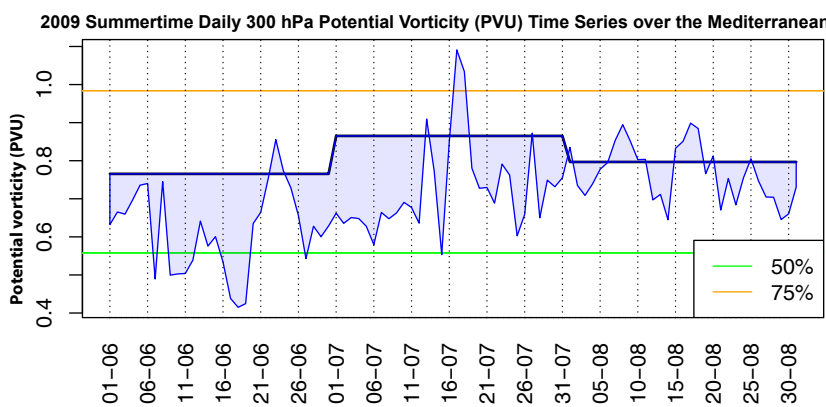

Figure 13. Same as Fig. 10 for the summer of 2009.

2009 (Pearson correlation coefficient of 0.44). This suggests that vertical exchange is not the major driving force for the ozone variability at $3 \mathrm{~km}$. Indeed, the IMI daily variation shows strong negative anomalies, indicating a lower diabatic convective activity than the climatological mean during June and July 2009. In order to investigate which other dynamical processes can play a key role in this low-ozone-value period, we examine the mean daily $850 \mathrm{hPa}$ geopotential value over the basin (Fig. 14). The Pearson correlation coefficient between the $3 \mathrm{~km}$ ozone observed by IASI and the $850 \mathrm{hPa}$ geopotential shows an anticorrelation with a value of -0.79 . For this period, the low values of $3 \mathrm{~km}$ ozone concentrations are then associated with high values of $850 \mathrm{hPa}$ geopotential (Fig. 14), whereas the high geopotential values were associated with high ozone values for June 2008. The difference between June 2008 and 2009 arises from the fact that the meteorological systems (high-/low-pressure structures) are not located in the same positions in June 2008 and 2009. Indeed, in 2009, the high-pressure levels are positioned over North Africa and the low-pressure levels are located over both the Atlantic and central Europe (Fig. 15a). These positions lead to a lower-tropospheric flux directed from the Atlantic Ocean to the Mediterranean Sea, inducing horizontal advection of oceanic clean-air masses over the Mediterranean, as it has been observed also during low-ozone-concentration periods in the area (Kalabokas et al., 2008, 2013). This meteorological situation persists from the beginning of June to the middle of July 2009 (Fig. 15b) and mainly explains the low values of lower-tropospheric ozone for June and July 2009.

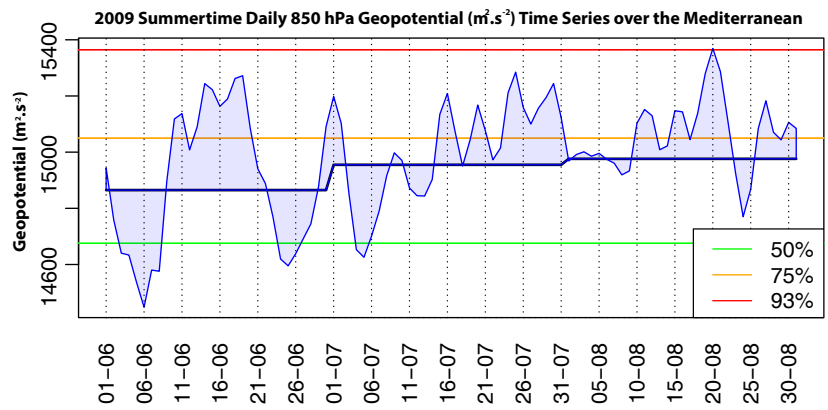

Figure 14. Same as Fig. 13 for $850 \mathrm{hPa}$ geopotential $\left(\mathrm{m}^{2} \mathrm{~s}^{-2}\right)$ taken from the $12 \mathrm{~h}$ ERA-Interim reanalysis.

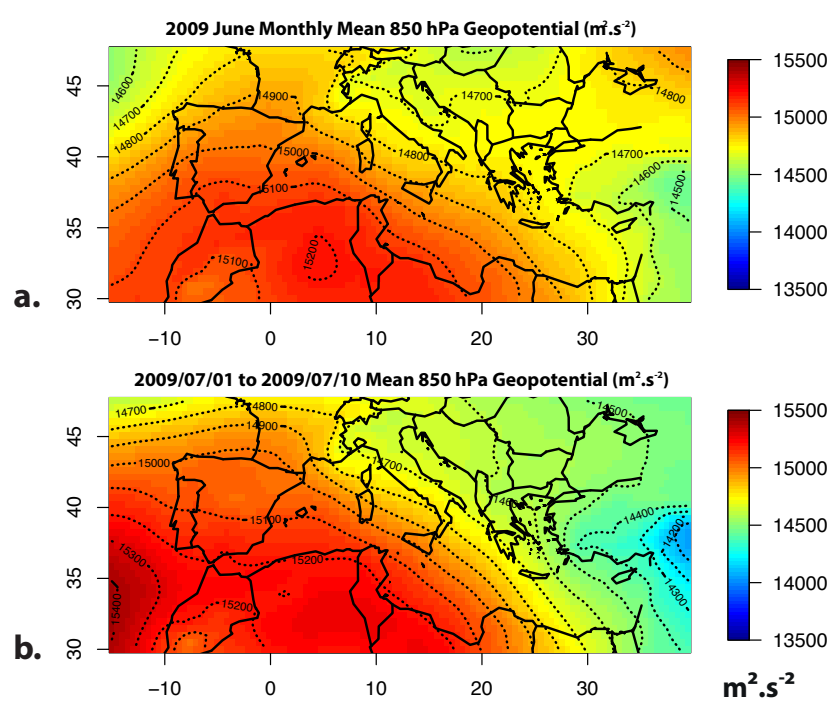

Figure 15. Mean $850 \mathrm{hPa}$ geopotential $\left(\mathrm{m}^{2} \mathrm{~s}^{-2}\right)$ for (a) the June 2009 period and (b) the 1-10 July 2009 period. Data are taken from the $12 \mathrm{~h}$ ERA-Interim reanalysis.

\section{Conclusions}

Six years (2007-2012) of satellite observations from IASI have been used to analyse the spatial and the temporal ozone variability over the Mediterranean basin during summertime (June, July, August). IASI observations with more than 200000 ozone profiles per summer over the Mediterranean basin provide a unique data set to investigate the intraseasonal variability of ozone in this region. The availability of the data since 2007 allows the characterization of the interannual ozone variability.

IASI ozone observations at a 3 and at a $10 \mathrm{~km}$ height provide reliable information for characterizing the lower- and the upper-tropospheric-ozone variability, respectively. In the lower troposphere, a steep west-east horizontal gradient over the basin is observed, in agreement with the summertime pool of high ozone concentrations over the eastern Mediterranean already reported in literature (e.g. Zanis et al., 2014). Vertical velocities at $500 \mathrm{hPa}$ and $300 \mathrm{hPa}$ potential vorticity 
(from ERA-Interim reanalysis) present similar pools of high values or gradients over the eastern basin, confirming the key role of the vertical exchanges in controlling the ozone concentrations in this region. Indeed, our analysis confirms that upper-tropospheric air masses with high ozone concentrations are efficiently transported downward into the middle and lower troposphere and largely modify the ozone budget over the central and eastern Mediterranean basin. In the upper troposphere, the monthly analysis of IASI ozone observations shows a June maximum (with respect to July and August) related to the annual cycle of upper-tropospheric ozone (spring maximum). In the lower troposphere, ozone concentrations exhibit a July maximum that is related mainly to the relative position and the intensification of the Azores anticyclone and the Middle Eastern depression associated with the Indian summer monsoon in July. Over the 6 years considered, the temporal evolution of ozone during summer turns out to be fairly stable. Nevertheless, two ozone anomalies were detected: June 2008, which presents high ozone concentrations compared to other years, and June and July 2009, which present unusually low ozone concentrations. The June 2008 anomaly is explained by an intensification of the vertical exchanges over the eastern basin, associated with stronger than usual anticyclonic conditions over the Mediterranean. The June and July 2009 anomaly is explained by the position of a strong anticyclone over North Africa and of lowpressure systems over the Atlantic and central Europe that induce transport of clean oceanic air masses over the Mediterranean. The relative position and the strength of the key meteorological systems (Azores anticyclone and Middle Eastern depression) are thus determinant factors for the ozone variability observed in the lower troposphere over the Mediterranean. In conclusion, the use of new data sets, namely, IASI tropospheric-ozone observations, allows us to reaffirm the hypothesis that downward transport of upper-tropospheric air masses to the middle and lower troposphere is responsible for the high ozone values and controls their variability. The possibility of a daily analysis (due to the high sampling capability of IASI) also permits us to show how horizontal fluxes (here the import of clean oceanic air masses over the basin) can perturb the mean situation. The impact of European emissions potentially connected to the Etesian winds has not been investigated here. Even if this impact is not dominant (Richards et al., 2013), it probably needs to be quantified more precisely. Recently, Safieddine et al. (2014) investigated this point using IASI ozone observations and regional WRF-CHEM (Weather Research and Forecasting model coupled with Chemistry) simulations.

Acknowledgements. This work has been done in the framwork of the MISTRALS/ChArMEx program. This study was supported by the French Space Agency CNES (project "IASI-TOSCA"). The IASI mission is a joint mission of Eumetsat and the Centre National d'Etudes Spatiales (CNES, France). The IASI L1 data are distributed in near-real time by Eumetsat through the
Eumetcast system distribution. The authors acknowledge the Ether French atmospheric database (http://ether.ipsl.jussieu.fr) for providing the IASI L1C and L2 data. The authors thank the Institut für Meteorologie und Klimaforschung (IMK), Karlsruhe Institute of Technology (KIT), Germany, for a licence to use the KOPRA radiative transfer model and especially $M$. Höpfner for his help in setting up the code. The ozone-sonde data used in this study were provided by the World Ozone and Ultraviolet Data Centre (WOUDC). The authors thank all those responsible for the WOUDC measurements and archives for making the ozone-sonde data available. Clément Doche is grateful to Météo-France for financial support. ECMWF ERA-Interim data used in this study have been obtained from the ECMWF data server.

Edited by: J. Ma

\section{References}

Alpert, P., Price, C., Krichak, S. O., Ziv, B., Saaroni, H., Osetinsky, I., Barkan, J., and Kishcha, P.: Tropical tele-connections to the Mediterranean climate and weather, Adv. Geosci., 2, 157-160, doi:10.5194/adgeo-2-157-2005, 2005.

Anagnostopoulou, C., Zanis, P., Katragkou, E., Tegoulias, I., and Tolika, K.: Recent past and future patterns of the Etesian winds based on regional scale climate model simulations, Clim. Dynam., 42, 1819-1836, 2014.

Beekmann, M., Ancellet, G., and Mégie, G.: Climatology of tropospheric ozone in Southern Europe and its relation to potential vorticity, J. Geophys. Res., 99, 12841-12853, 1994.

Beer, R., Glavich, T. A., and Rider, D. M.: Tropospheric Emission Spectrometer for the Earth Observing System's Aura satellite, Appl. Opt., 40, 2356-2367, 2001.

Boynard, A., Clerbaux, C., Coheur, P.-F., Hurtmans, D., Turquety, S., George, M., Hadji-Lazaro, J., Keim, C., and MeyerArnek, J.: Measurements of total and tropospheric ozone from IASI: comparison with correlative satellite, ground-based and ozonesonde observations, Atmos. Chem. Phys., 9, 6255-6271, doi:10.5194/acp-9-6255-2009, 2009.

Camredon, M. and Aumont, B.: Modélisation de l'ozone et des photooxydants troposphériques. I. L'ozone troposphérique : production/consommation et régimes chimiques, Pollution Atmosphérique, 193, 51-60, 2007.

Clarisse, L., R'Honi, Y., Coheur, P.-F., Hurtmans, D., and Clerbaux, C.: Thermal infrared nadir observations of 24 atmospheric gases, Geophys. Res. Lett., 38, L10802, doi:10.1029/2011GL047271, 2011.

Clerbaux, C., Boynard, A., Clarisse, L., George, M., Hadji-Lazaro, J., Herbin, H., Hurtmans, D., Pommier, M., Razavi, A., Turquety, S., Wespes, C., and Coheur, P.-F.: Monitoring of atmospheric composition using the thermal infrared IASI/MetOp sounder, Atmos. Chem. Phys., 9, 6041-6054, doi:10.5194/acp-9-6041-2009, 2009.

Coheur, P.-F., Barret, B., Turquety, S., Hurtmans, D., Hadji-Lazaro, J., and Clerbaux, C.: Retrieval and characterization of ozone vertical profiles from a thermal infrared nadir sounder, J. Geophys. Res., 110, D24303, doi:10.1029/2005JD005845, 2005.

Cuesta, J., Eremenko, M., Liu, X., Dufour, G., Cai, Z., Höpfner, M., von Clarmann, T., Sellitto, P., Foret, G., Gaubert, B., Beekmann, M., Orphal, J., Chance, K., Spurr, R., and Flaud, J.-M.: 
Satellite observation of lowermost tropospheric ozone by multispectral synergism of IASI thermal infrared and GOME-2 ultraviolet measurements over Europe, Atmos. Chem. Phys., 13, 9675-9693, doi:10.5194/acp-13-9675-2013, 2013.

Dee, D. P., Uppala, S. M., Simmons, A. J., Berrisford, P., Poli, P., Kobayashi, S., Andrae, U., Balmaseda, M. A., Balsamo, G., Bauer, P., Bechtold, P., Beljaars, A. C. M., van de Berg, L., Bidlot, J., Bormann, N., Delsol, C., Dragani, R., Fuentes, M., Geer, A. J., Haimberger, L., Healy, S. B., Hersbach, H., Hólm, E. V., Isaksen, L., Kållberg, P., Köhler, M., Matricardi, M., McNally, A. P., Monge-Sanz, B. M., Morcrette, J.-J., Park, B.-K., Peubey, C., de Rosnay, P., Tavolato, C., Thépaut, J.-N., and Vitart, F.: The ERA-Interim reanalysis: configuration and performance of the data assimilation system, Q. J. R. Meteorol. Soc., 137, 553-597, doi:10.1002/qj.828, 2011

Delmas, R., Mégie, G., and Peuch, V.-H.: Physique et chimie de l'atmosphère, Ed. Belin, Coll. Echelles, 640, 2005.

Dufour, G., Eremenko, M., Orphal, J., and Flaud, J.-M.: IASI observations of seasonal and day-to-day variations of tropospheric ozone over three highly populated areas of China: Beijing, Shanghai, and Hong Kong, Atmos. Chem. Phys., 10, $3787-$ 3801, doi:10.5194/acp-10-3787-2010, 2010.

Dufour, G., Eremenko, M., Griesfeller, A., Barret, B., LeFlochmoën, E., Clerbaux, C., Hadji-Lazaro, J., Coheur, P.-F., and Hurtmans, D.: Validation of three different scientific ozone products retrieved from IASI spectra using ozone-sondes, Atmos. Meas. Tech., 5, 611-630, doi:10.5194/amt-5-611-2012, 2012.

Eremenko, M., Dufour, G., Foret, G., Keim, C., Orphal, J., Beekmann, M., Bergametti, G., and Flaud, J.-M.: Tropospheric ozone distributions over Europe during the heat wave in July 2007 observed from infrared nadir spectra recorded by IASI, Geophys. Res. Lett., 35, L18805, doi:10.1029/2008GL034803, 2008.

Fishman, J., Wozniak, A. E., and Creilson, J. K.: Global distribution of tropospheric ozone from satellite measurements using the empirically corrected tropospheric ozone residual technique: Identification of the regional aspects of air pollution, Atmos. Chem. Phys., 3, 893-907, doi:10.5194/acp-3-893-2003, 2003.

Foret, G., Eremenko, M., Cuesta, J., Sellitto, P., Barré, J., Gaubert, B., Coman, A., Dufour, G., Liu, X., Joly, M., Doche, C., and Beekmann, M.: Ozone pollution: What can we see from space? A case study, J. Geophys. Res. Atmos., 119, 8476-8499, doi:10.1002/2013JD021340.

Fuhrer, J.: Ozone risk for crops and pastures in present and future climates, Naturwissenschaften, 96, 173-194, 2009.

George, M., Clerbaux, C., Hurtmans, D., Turquety, S., Coheur, P.F., Pommier, M., Hadji-Lazaro, J., Edwards, D. P., Worden, H., Luo, M., Rinsland, C., and McMillan, W.: Carbon monoxide distributions from the IASI/METOP mission: evaluation with other space-borne remote sensors, Atmos. Chem. Phys., 9, 8317-8330, doi:10.5194/acp-9-8317-2009, 2009.

Holton, J. R.: An introduction to dynamic meteorology, third edition, Academic Press, Inc. San Diego, California, 1992.

Hopfner, M., Blom, C. E., Echle, G., Glatthor, N., Hase, F., and Stiller, G.: Retrieval simulations for MIPAS-STR measurements, edited by: Smith, W. L., IRS 2000: Current Problems in Atmospheric Radiation, Proc. of the Internat. Radiation Symp., St. Petersburg, Russia, 24-29 July 2000, Hampton, Va., DEEPAK Publ., 2001.
Hoskins, B. J., McIntyre, M. E., and Robertson, A. W.: On the use and significance os isentropic potential vorticity maps, Q. J. Roy. Meteor. Soc., 111, 877-946, 1945.

IPCC: Climate Change 2007: The Physical Science Basis, Contribution of Working Group I to the Fourth Assessment Report of the Intergovernmental Panel on Climate Change, edited by: Solomon, S., Qin, D., Manning, M., Chen, Z., Marquis, M., Averyt, K. B., Tignor, M., and Miller, H. L., Cambridge University Press, Cambridge, United Kingdom and New York, NY, USA, 2007.

Jacob, D. J.: Heterogeneous chemistry and tropospheric ozone, Atmos. Env., 34, 2131-2159, 2000.

Jones, D. B. A., Bowman, K. W., Horowitz, L. W., Thompson, A. M., Tarasick, D. W., and Witte, J. C.: Estimating the summertime tropospheric ozone distribution over North America through assimilation of observations from the Tropospheric Emission Spectrometer, J. Geophys. Res., 113, D18307, doi:10.1029/2007JD009341, 2008.

Jonson, J. E., Sunder, J. K., and Tarrasón, L.: Model calculations of present and future levels of ozone and ozone precursors with a global and regional model, Atmos. Environ., 35, 525-537, 2001.

Kalabokas, P. D. and Repapis, C. C.: A climatological study of rural surface ozone in central Greece, Atmos. Chem. Phys., 4, 1139 1147, doi:10.5194/acp-4-1139-2004, 2004.

Kalabokas, P. D., Mihalopoulos, N., Ellul, R., Kleanthous, S., and Repapis, C. C.: An investigation of the meteorological and photochemical factors influencing the background rural and marine surface ozone levels in the Central and Eastern Mediterranean, Atmos. Environ., 42, 7894-7906, 2008.

Kalabokas, P. D., Cammas, J.-P., Thouret, V., Volz-Thomas, A., Boulanger, D., and Repapis, C. C.: Examination of the atmospheric conditions associated with high and low summer ozone levels in the lower troposphere over the eastern Mediterranean, Atmos. Chem. Phys., 13, 10339-10352, doi:10.5194/acp-1310339-2013, 2013.

Keim, C., Eremenko, M., Orphal, J., Dufour, G., Flaud, J.-M., Höpfner, M., Boynard, A., Clerbaux, C., Payan, S., Coheur, P.-F., Hurtmans, D., Claude, H., Dier, H., Johnson, B., Kelder, H., Kivi, R., Koide, T., López Bartolomê, M., Lambkin, K., Moore, D., Schmidlin, F. J., and Stübi, R.: Tropospheric ozone from IASI: comparison of different inversion algorithms and validation with ozone sondes in the northern middle latitudes, Atmos. Chem. Phys., 9, 9329-9347, doi:10.5194/acp-9-9329-2009, 2009.

Kulawik, S. S., Osterman, G., Jones, D. B. A., and Bowman, K. W.: Calculation of altitude-dependent Tikhonov constraints for TES nadir retrievals, IEEE T. Geosci. Remote, 44, 1334-1342, 2006.

Lelieveld, J., Berresheim, H., Borrmann, S., Crutzen, P. J., Dentener, F. J., Fischer, H., de Gouw, J., Feichter, J., Flatau, P., Heland, J., Holzinger, R., Korrmann, R., Lawrence, M., Levin, Z., Markowicz, K., Mihalopoulos, N., Minikin, A., Ramanathan, V., de Reus, M., Roelofs, G.-J., Scheeren, H. A., Sciare, J., Schlager, H., Schultz, M., Siegmund, P., Steil, B., Stephanou, E., Stier, P., Traub, M., Williams, J., and Ziereis, H.: Global air Pollution crossroads over the Mediterranean, Science, 298, 794-799, 2002.

Levy, J. I., Carrothers, T. J., Tuomisto, J. T., Hammitt, J. K., and Evans, J. S.: Assessing the Public Health Benefits of Reduced Ozone Concentrations, Environ. Health Perspect., 109, 12151226, 2001. 
Li, Q., Jacob, D. J., Logan, J. A., Bey, I., Yantosca, R. M., Liu, H., Martin, R. V., Fiore, A. M., Field, B. D., Duncan, B. N., and Thouret, V.: A tropospheric ozone maximum over the Middle East, Geophys. Res. Lett., 28, 3235-3238, doi:10.1029/2001GL013134, 2001.

Liu, X., Chance, K. V., Sioris, C. E., Spurr, R. J. D., Kurosu, T. P., Martin, R. V., and Newchurch, M. J.: Ozone profile and tropospheric ozone retrievals from Global Ozone Monitoring Experiment: Algorithm description and validation, J. Geophys. Res., 110, D20307, doi:10.1029/2005JD006240, 2005.

Liu, J. J., Jones, D. B. A., Worden, J. R., Noone, D., Parrington, M., and Kar, J.: Analysis of the summertime buildup of tropospheric ozone abundances over the Middle East and North Africa as observed by the Tropospheric Emission Spectrometer intrument, J. Geophys. Res., 114, D05304, doi:10.1029/2008JD010993, 2009.

Marenco, A., Thouret, V., Nédélec, P., Smit, H., Helten, M., Kley, D., Karcher, F., Simon, P., Law, K., Pyle, J., Poschmann, G., Von Wrede, R., Hume, C., and Cool, T.: Measurement of ozone water vapor by Airbus in-service aircraft: The MOZAIC airborne program, An overview, J. Geophys. Res., 103, 25631-25642, doi:10.1029/98JD00977, 1998.

McPeters, R. D., Labow, G. J., and Logan, J. A.: Ozone climatological profiles for satellite retrieval algorithms, J. Geophys. Res., 112, D05308, doi:10.1029/2005JD006823, 2007.

Millan, M., Mantilla, E., Salvador, R., Carratala, A., Sanz, M. J., Alonso, L., Gangoiti, G., and Navazo, M.: Ozone cycles in the western Mediterranean basin: interpretation of monitoring data in complex coastal terrain, J. Appl. Meteorol., 4, 487-507, 2000.

Nolle, M., Ellul, R., Heinrich, G., and Güsten, H.: A long-term study of background ozone concentrations in the central Mediterranean - diurnal and seasonal variations on the island of Gozo, Atmos. Env., 36, 1391-1402, 2001.

Prezerakos, N. G.: Does the extension of the Azores' anticyclone towards the Balkans really exist, Arch. Meteorol. Geophys. Bioclimatol. Ser. A., 33, 217-227, 1984.

Richards, N. A. D., Arnold, S. R., Chipperfield, M. P., Miles, G., Rap, A., Siddans, R., Monks, S. A., and Hollaway, M. J.: The Mediterranean summertime ozone maximum: global emission sensitivities and radiative impacts, Atmos. Chem. Phys., 13, 2331-2345, doi:10.5194/acp-13-2331-2013, 2013.

Roelofs, G. J., Scheeren, H. A., Heland, J., Ziereis, H., and Lelieveld, J.: A model study of ozone in the eastern Mediterranean free troposphere during MINOS (August 2001), Atmos. Chem. Phys., 3, 1199-1210, doi:10.5194/acp-3-1199-2003, 2003.

Safieddine, S., Clerbaux, C., George, M., Hadji-Lazaro, J., Hurtmans, D., Coheur, P.-F., Wespes, C., Loyola, D., Valks, P., and Hao, N.: Tropospheric ozone and nitrogen dioxide measurements in urban and rural regions as seen by IASI and GOME-2, J. Geoph. Res.: Atmospheres 118, 18, 10555-10566, 2013.

Safieddine, S., Boynard, A., Coheur, P.-F., Hurtmans, D., Pfister, G., Quennehen, B., Thomas, J. L., Raut, J.-C., Law, K. S., Klimont, Z., Hadji-Lazaro, J., George, M., and Clerbaux, C.: Summertime tropospheric ozone assessment over the Mediterranean region using the thermal infrared IASI/MetOp sounder and the WRF-Chem model, Atmos. Chem. Phys., 14, 1011910131, doi:10.5194/acp-14-10119-2014, 2014.
Sprenger, M., Wernli, H., and Bourqui, M.: StratosphereTroposphere Exchange and Its Relation to Potential Vorticity Streamers and Cutoffs near the Extratropical Tropopause, J. Atmos. Sci., 64, 1587-1602, doi:10.1175/JAS3911.1, 2007.

Stiller, G. P.: The Karlsruhe optimized and precise radiative transfer algorithm (KOPRA), FZKA, 2000.

Stohl, A., James, P., Forster, C., Spinchtinger, N., Marenco, A., Thouret, V., and Smit, H. G. J.: An extension of MOZAIC ozone climatologies using trajectory statistics, J. Geophys. Res., 106, 27757-27768, 2001.

Tyrlis, E. and Lelieveld, J.: Climatology and dynamics of the summer Etesian winds over the Eastern Mediterranean, J. Atmos. Sci., 70, 3374-3396, doi:10.1175/JAS-D-13-035.1, 2013.

Tyrlis, E., Škerlak, B., Sprenger, M., Wernli, H., Zittis, G., and Lelieveld, J.: On the linkage between the Asian summer monsoon and tropopause fold activity over the eastern Mediterranean and the Middle East, J. Geophys. Res. Atmos., 119, 3202-3221, doi:10.1002/2013JD021113, 2014.

Velchev, K., Cavalli, F., Hjorth, J., Marmer, E., Vignati, E., Dentener, F., and Raes, F.: Ozone over the Western Mediterranean Sea - results from two years of shipborne measurements, Atmos. Chem. Phys., 11, 675-688, doi:10.5194/acp-11-675-2011, 2011.

Volz-Thomas, A., Beekmann, M., Derwent, D., Law, K., Lindskog, A., Prévôt, A., Roemer, M., Schultz, M., Schurath, U., Solberg, S., and Stohl, A.: Tropospheric Ozone and its Control, Towards Cleaner Air for Europe - Science, Tools and Applications, Chap. 3, Synthesis and Integration (S\&I) Project, 2003.

WMO: International list of selected and supplementary ships, 3, WMO 47 (WMO/OMM 47, TP. 18), 143 pp., 1957.

Worden, H. M., Logan, J. A., Worden, J. R., Beer, R., Bowman, K., Clough, S. A., Eldering, A., Fisher, B. M., Gunson, M. R., Herman, R. L., Kulawik, S. S., Lampel, M. C., Luo, M., Megretskaia, I. A., Osterman, G. B., and Shephard, M. W.: Comparisons of Tropospheric Emission Spectrometer (TES) ozone profiles to ozone-sondes: Methods and initial results, J. Geophys. Res., 112, D03309, doi:10.1029/2006JD007258, 2007.

Worden, H. M., Bowman, K. W., Eldering, A., and Beer, R.: Satellite measurements of the clear sky greenhouse effect from tropospheric ozone, Nat. Geosci., 1, 305-308, doi:10.1038/ngeo182, 2008.

Zanis, P., Hadjinicolaou, P., Pozzer, A., Tyrlis, E., Dafka, S., Mihalopoulos, N., and Lelieveld, J.: Summertime free-tropospheric ozone pool over the eastern Mediterranean/Middle East, Atmos. Chem. Phys., 14, 115-132, doi:10.5194/acp-14-115-2014, 2014.

Zbinden, R. M., Thouret, V., Ricaud, P., Carminati, F., Cammas, J.P., and Nédélec, P.: Climatology of pure tropospheric profiles and column contents of ozone and carbon monoxide using MOZAIC in the mid-northern latitudes $\left(24^{\circ} \mathrm{N}\right.$ to $\left.50^{\circ} \mathrm{N}\right)$ from 1994 to 2009, Atmos. Chem. Phys., 13, 12363-12388, doi:10.5194/acp13-12363-2013, 2013.

Ziv, B., Saaroni, H., and Alpert, P.: The factors governing the summer regime of the eastern Mediterranean, Int. J. Climatol., 24, 1859-1871, 2004. 